Article

\title{
Potential for Producing Biogas from Agricultural Waste in Rural Plants in Poland ${ }^{\dagger}$
}

\section{Magdalena Muradin ${ }^{\star}$ and Zenon Foltynowicz ${ }^{\ddagger} *$}

Faculty of Commodity Science, Poznań University of Economics, al. Niepodległości 10, Poznań 61875, Poland; E-Mail: magdalena.muradin@phd.ue.poznan.pl

$\dagger$ Preliminary results were presented on Third International Conference "Industrial and Hazardous Waste Management”, Chania, Greece, 12-14 September 2012.

\# These authors contributed equally to this work.

* Author to whom correspondence should be addressed; E-Mail: zenon.foltynowicz@ue.poznan.pl; Tel.: +48-61-856-9214; Fax: +48-61-854-3993.

Received: 18 July 2014 / Accepted: 30 July 2014 / Published: 8 August 2014

\begin{abstract}
This article is an overview of the current situation as well as future prospects for biogas production in rural plants in Poland. Our research has focused on the management of agricultural waste. While Poland's agriculture and its local food industry have substantial potential, many barriers persist to the development not only of biogas plants but also in every other renewable source of energy. The main obstacles have to do with politically motivated economic factors. Our interest has been in larger plants having sufficient capacities to produce in excess of $500 \mathrm{~kW}$ of electricity. The paper also presents a case study of a biogas plant supply by organic, agrifood waste mixed with silage.
\end{abstract}

Keywords: agriculture waste; biomass; biogas; biogas plant

\section{Introduction}

Energy production in Poland relies predominantly on conventional energy sources, particularly coal. In fact, mining is one of Poland's chief industries. After Poland acceded to the European Union in 2004, it had to comply with regulations which prevailed throughout the EU. One such instrument is Directive 2009/28/EC which envisions that the EU increase its share of renewables in ultimate energy consumption in individual member states to $20 \%$ by the year 2020 [1]. To meet these requirements, 
Poland needs to reduce its coal combustion in coal-fired power plants so that $15 \%$ of its ultimate energy consumption comes from renewable sources by the year 2020. An arrangement considered and promoted to minimize carbon emissions from coal combustion in coal-fired plants, and one which Poland has committed to by signing the Kyoto Protocol, is to build a nuclear power station. This goes against the global trend of abandoning nuclear power, which has gained particular momentum since the Fukushima disaster in Japan of 2011. In its aftermath, Germany has committed to phase out its own nuclear power. All this puts a question mark over the growth of the nuclear sector in Poland. The idea is also facing strong public resistance and is viewed as highly controversial.

Crude oil reserves are predicted to run out by 2050 while the global deposits of gas and coal are expected to deplete rapidly. Not only the EU but also the rest of the world is convinced that it is time to invest in green energy. Foreign investors have come to Poland to launch engineering projects in which renewables such as wind, hydropower, biomass, geothermal heat and solar energy are used to produce power. Poland is slowly waking up to the fact that investing in renewable energy makes sense and brings tangible benefits. Regrettably, however, the Polish government seems to remain oblivious to such developments. Relevant legislation on the forms and levels of support for renewable energy is still to be adopted. Poland was obliged to comply with Directive [1] by 2010. Having failed to do so, it now faces penalties to the tune of $€ 133,000$ for each day of delay. The case has been brought before the Court of Justice of the European Union in Strasbourg.

Poland's geographical location prevents it from exploring some forms of energy on a large scale. The most promising of them seems to be biomass. Unlike other technologies which use biomass to produce energy, biogas plants go beyond mere energy production. They are ideally suited for utilizing environmentally harmful waste from agri-food processing and its post-fermentation products which form valuable natural fertilizer. Under the Polish law, rural biogas plants may produce agricultural biogas from such raw materials as organic agricultural products, liquid or solid animal manure, agri-food industry by-products or residues and forest biomass with the exception of biogas from wastewater treatment plants and landfills [2]. No biogas plants in Poland produce biogas from biodegradable municipal waste currently composted or disposed of in municipal landfills. The reason for this is that Polish legislation fails to deem biogas produced from municipal organic waste as agricultural biogas. This in fact creates a number of administrative and economic challenges. Although plants fired by organic waste generated in food processing produce biogas which does enjoy this status, they are not sufficiently promoted.

Another serious difficulty faced by biogas plants relying on organic waste is strong public opposition which results mainly from the lack of reliable information about biogas. Although the method utilizes a biological process known since prehistory, the technology itself remains relatively new. The most common objections have to do with onerous smells, epidemiological risks and environmental pollution.

\subsection{Situation in Poland}

The potential of agricultural gas in Poland exceeds that of any other renewable energy available in the country. Nevertheless, its development remains hampered by the lack of relevant legislation. Poland's potential to use biomass to produce biogas is comparable to that found in other EU member 
states where the adoption of laws supporting renewable contributed to rapid market saturation. While Poland is currently home to some 200 operating biogas plants, only 33 of them produce biogas. The majority make energy from energy crops, mainly maize silage, and animal waste, i.e., manure. There is, however, a noticeable trend to move away from such practices in favor of agri-food waste such as spent wash or potato pulp whose disposal is problematic (see Table 1). The remaining biogas facilities are located at wastewater treatment plants or landfills. These produce landfill biogas. In 2011, rural biogas plants have produced $73.43 \mathrm{GWh}$ of electric and $88.8 \mathrm{GWh}$ of thermal energy (see Table 2). In 2012, the output of electric and thermal energy increased twofold in terms of value. In spite of an unfavorable political climate contributing to a steady decline in the value of certificates, last year saw the opening of 11 new biogas plants, each with a capacity of $0.5 \mathrm{MW}$. In view of the most recent developments in biogas production, such output has been on the rise. The trend, however, is relatively slow and far from satisfactory [3].

Table 1. Quantity of raw material used to produce agricultural biogas in 2011-2012 based on reports from Agricultural Market Agency [4].

\begin{tabular}{lcc}
\hline \multirow{2}{*}{$\begin{array}{c}\text { Type of raw material used to } \\
\text { produce agricultural biogas }\end{array}$} & \multicolumn{2}{c}{$\begin{array}{c}\text { Quantity of raw material used to produce } \\
\text { agricultural biogas [in tons] }\end{array}$} \\
\cline { 2 - 3 } & Total in 2011 & Total in 2012 \\
\hline Energy crops including grass & $123,678.81$ & $244,781.93$ \\
\hline Animal waste & $277,601.32$ & $372,650.42$ \\
\hline Agri-food waste & $68,135.93$ & $313,575.13$ \\
\hline
\end{tabular}

Table 2. Production of biogas, electric and thermal energy in 2011 and 2012 in rural biogas plants based on quarterly reports from Agricultural Market Agency [4].

\begin{tabular}{cccc}
\hline Year & $\begin{array}{c}\text { Production of } \\
\text { biogas [ } \mathbf{m} \mathbf{n} \mathbf{~ m}^{\mathbf{3}} \text { ] }\end{array}$ & $\begin{array}{c}\text { Production of electric } \\
\text { energy from biogas [GWh] }\end{array}$ & $\begin{array}{c}\text { Production of heat energy } \\
\text { from biogas [GWh] }\end{array}$ \\
\hline 2011 & 36.64 & 73.43 & 88.80 \\
\hline 2012 & 73.14 & 141.79 & 158.64 \\
\hline
\end{tabular}

Poland has not yet transposed Directive 2009/28/EC on the promotion of renewable sources of energy. The deadline for all member states to comply with the Directive, which aims at achieving a $20 \%$ share of energy from renewable sources in the overall energy mix by 2020 , for all Member States was 5 December 2010. Thus far, Poland has not passed a law to at least regulate the amount of aid for renewable energy installations. Meanwhile, all energy certificates obtained for high-efficiency cogeneration have expired.

\subsection{Biomass Potential}

Given the enormous potential of biomass available for use in its biogas plants, Poland could well join the member states which lead in the production of biogas from rural feedstock. Poland has very robust agriculture and food industry [5]. It boasts highly advanced pork and poultry production as well as expansive arable lands with good quality soils and a climate well-suited for growing a wide variety of energy crops. The Polish climate is moderate with the average total amount of rainfall ranging from 
500 to $700 \mathrm{~mm}$ annually. The country's predominant lowlands facilitate agricultural production. It is difficult, however, to measure the true potential of biomass and biogas in Poland as no credible sources of relevant data are available. According to the 2010 data provided by the Ministry of Economy, the potential for biogas production stands at 1.7 million cubic meters per annum [6].

In the course of its public consultations on Directive 2009/28/EC, the European Commission firmly insisted that biogas production be based mainly on processing agricultural and agri-food industry waste [3]. The fact that Poland significantly increased its use of agricultural waste substrates between 2011 and 2012 (see Table 2) demonstrates that biogas plants are gradually venturing beyond mere energy production. Their additional advantage is that they utilize environmentally harmful agri-food waste which, incidentally, increases their profitability through the use of low-cost charges. In addition, the use of animal waste has not increased in proportion to that of other substrates. What has changed, however, is the location of biogas plants which are now being built closer to food processing operators rather than farms. As an example, a nearly fivefold increase has been reported in the use of distillers' grain for the production of biogas. Its volume rose from ca. 30,000 tons in 2011 to ca. 130,000 tons in 2012 [4]. This is primarily the result of difficulties with managing this type of waste and the legislative restrictions on its disposal imposed by the EU.

The most difficult part of designing a biogas plant is to estimate the availability of adequate quantities of substrates needed to run the plant at full capacity. A suitable plant site should offer the potential of securing sufficient amounts of substrate in its close proximity. This will not only cut costs but also turn the biogas plant into a diversified local source of energy. One can follow the German example and build biogas plants which rely solely on maize silage and manure. Another idea for Poland could be to place biogas plants close to agri-food companies with a view to reducing the cost of procuring raw materials. This could be achieved to a large extent by utilizing the large amounts of slaughterhouse waste which is available for biogas production, especially in the Wielkopolska Region [3]. Studies on biogas plants show that the co-digestion of industrial waste and energy crops improves process performance and stability. It also eliminates the need for micronutrients required for crop digestion [7].

\subsection{Biogas Plants-State of Play}

The failure of the renewable energy sector to achieve the expected growth can be attributed to a variety of economic, political and social factors. The biggest challenge seems to lie in the lack of legal regulations concerning renewable energy sources. The current support system fails to guarantee market stability, thus discouraging investors and impeding development.

Although much has been said in recent years on changes which would fuel the rise of renewables, no tangible progress seems to have followed. In 2007, in its Communication to the Council and the European Parliament, the European Commission noted that considering the low price of green certificates in Poland, the country is expected to rapidly increase its share of electricity generated from renewable energy sources, especially in view of its high obligations with that respect [8]. Little has actually changed since that time. The support system is still weak and the uncertainty associated with the lack of legal regulations slows down investor activity. As the green certificate market collapsed in 2012 due to an oversupply on the Polish Energy Exchange, certificate prices fell to PLN 130. 
In addition, the previous plan to support electric and thermal energy production with efficient co-generation was abandoned in March 2013. This put a stop to the development of biogas in Poland seriously jeopardizing the achievement of renewable energy targets for 2020 (a 15\% share of renewable energy in ultimate energy consumption in all sectors, including $19 \%$ for the electric power sector) [9]. To ensure that biogas plants operate at a profit, their construction needs to be subsidized. For technological reasons, less profitable biogas plants run only on maize silage and are ill-suited to take advantage of other feedstocks. The approximate cost of 1 ton of silage at gate is PLN 130 . In Germany, where biogas plants have grown rapidly, investors focus primarily on maize silage rather than limiting themselves to manure. Meanwhile, Poland's high prices of fresh maize effectively deter investors [10].

Investors are also discouraged by the administrative burden of mandatory procedures involved in obtaining the required permits. The first requirement they face is to obtain an environmental permit based on environmental impact assessments. Such assessments are a key instrument of the EU's environmental protection policy, their intention being to protect natural sites potentially endangered by new development. Impact assessments are prerequisite to obtaining EU funds for the construction of road infrastructure [11]. They require lengthy public consultations. This in itself would not be difficult were it not for massive public resistance to projects which stem from a number of concerns rooted mainly in public ignorance. Of about 350 biogas plants seeking permits, 130 have encountered overt social resistance [12]. Some of the most notable among the many reasons for such protests are:

- the fear of change;

- the lack of reliable information on biogas and its production;

- the NIMBY (Not In My Back Yard) effect;

- the work of proactive opponents relying on manipulated data (and frequently acting on personal grounds).

Political support for biogas installations is another problem. While many politicians staunchly support large-scale development of renewable energy sources, they are also in favor of building nuclear power plants. A strategic document published by the Ministry of Economy presents an ambitious plan to construct two thousand biogas plants by the year 2020 to place "a biogas plant in each municipality" [6]. This would result in the construction of an estimated 3000 facilities, each with an average capacity of $1 \mathrm{MW}$. Their total combined output would be comparable to that of a single nuclear power plant. Such a huge number of biogas plants would require not only the involvement of private capital but also the support of the Polish government [8]. Moreover, as no large-scale activities (such as information campaigns) exist to promote renewable energy sources unreliable information tends to be exaggerated fueling public resistance.

About 90 percent of the electricity produced in Poland is generated from coal. This makes the energy sector a major polluter. As most of the mining industry is state rather than privately owned, the state, which supports the development of RES in view of its commitments towards the EU, is also very reluctant to allow renewable energy to dominate the Polish energy sector as this is not in its interest.

The Polish energy sector is torn by huge technical disparities as its technical infrastructure is ill-adapted to fulfill the functional needs and requirements of its customers. This is true for capacities, their distribution and power grids. For instance, $39 \%$ of power facilities will be more than 40 years old 
by 2010 [13]. A major problem faced by for investors is that they are not allowed to connect their plants to the grid. Obviously, energy operators cannot keep energy from renewable sources from being connected and fed into the grid. They may however declare such connections impossible due to the lack of spare capacities or inadequate grid infrastructure at energy source. The preferred suppliers of energy companies are biogas plants as the electricity produced from biogas is more stable and steady compared to other renewable.

Installation projects are also hampered by the lack of appropriate laws to govern residues. Residues in Poland continue to be treated as waste and are expected to be used in agriculture as fertilizer. However, to fulfill the requirement, biogas plant owners would need to have sufficient land of their own on which to spread their residues. Before slaughterhouse waste or other animal waste can be applied in the fermentation process, regular soil tests for the presence of heavy metals must be conducted. Under such circumstances, it is considerably more convenient to build a biogas plant at the farm where the feedstock of manure and maize corn is available for use than to opt for biogas plants which run on organic waste from the agri-food industry. The fact that residues are classified as waste creates additional legal problems related to waste management. What deters investors is that they are kept from selling residues as fertilizer for additional income. Therefore, a pressing need exists to adopt appropriate laws on renewable energy, particularly in the context of the treatment of fermentation residues.

\section{Experimental Section}

\section{Case Study: Description of Biogas Plant}

Provided below is a case study of the first Polish biogas plant to process organic waste sourced from the food industry. The facility, which has been in operation for over two years, was built by Poland's first enterprise to venture into the biogas industry.

The biogas plant was built in the Wielkopolska Region, in a municipality where agriculture is the predominant form of land use. It was placed next to an agricultural distillery with which it has a business relationship.

The distillery supplies the plant with silage in return for heat provided in the form of water vapor generated by hot exhaust gases passing through a steam generator following the combustion of biogas in a co-generator. The biogas installation relies on wet mesophilic digestion at $37^{\circ} \mathrm{C}$. The fermenters are charged with about 80 tons of feedstock per day. The amount of charge varies from one season to another (see Table 3). As the potato pulp stored in the silo freezes in the winter, which reduces the amount of available substrate, biogas fermenters are charged with maize silage to sustain full power-producing capacity. The plant was built by "learning as you go". As Poland's first installation of its kind, the facility became a reference biogas plant. As a consequence, a great deal of additional equipment was added to prepare the installation for the use of diverse feedstocks. The plant is suited for processing slaughterhouse waste which, under Directive 2001/77/EC, has to be purified before being placed in a fermenter. However, due to developments in the slaughterhouse waste sector, it is no longer profitable to use such waste in biogas plants. The project has been financed by two main sources of funding (see Table 4). 
Table 3. Daily use of feedstock (based on data collected in Q3 2012).

\begin{tabular}{lc}
\hline Feedstock type & Feedstock quantity [t/day] \\
\hline Corn silage & 6.526 \\
\hline Potato pulp & 6.360 \\
\hline Spent wash (vinasse) & 33.271 \\
\hline Fruit and vegetable pomace & 1.95 \\
\hline Cereals & 0.270 \\
\hline Plant tissue waste & 1.4 \\
\hline Sludge from on-site waste water treatment plant & 3.1 \\
\hline Soya oil & 0.006 \\
\hline TOTAL & 52.883 \\
\hline
\end{tabular}

Table 4. Sources of funding (author's studies based on data from investor).

\begin{tabular}{lcc}
\hline Sources of funds & amount [€] & share [\%] \\
\hline Investor's own resources & 787,966 & 25 \\
\hline Investment loan & $1,418,338$ & 45 \\
\hline EU funding & 945,559 & 30 \\
\hline Total & $\mathbf{3 , 1 5 1 , 8 6 3}$ & \\
\hline
\end{tabular}

While the biogas plant was launched in March 2011, it did not achieve its maximum capacity until October 2011. The plant generates $0.526 \mathrm{MW}$ of electricity and offers $0.558 \mathrm{MW}$ of heat. $0.2 \mathrm{MW}$ of heat in the form of hot water vapor goes to the distillery whereas the remainder comes in the form of hot water. According to data obtained in the third quarter of 2012, the plant produced $9.854 \mathrm{MWh}$ of electricity and $10.466 \mathrm{MWh}$ of heat per day putting out an average total $7417 \mathrm{MWh}$ of energy per annum. In the theoretical precepts adopted in calculating profits from the sale of energy, the average annual time of gas engine operation was estimated at $8000 \mathrm{~h}$ (inclusive of maintenance down time). This made it possible to find that the biogas plant operated at $92.7 \%$ of its projected capacity in Q3 2012.

\section{Results and Discussion}

\section{Net Present Value of Biogas Plant}

The table below shows results of economic studies carried out for the biogas plant based on organic waste from agri-food industry discussed in the case study (see Table 5). The biogas plant produced ample profit until the green certificates market collapsed in the late 2012. The net present value of the project's discount rate (of 7.5\%) for 2012 was assumed to be a function of interest on outstanding loans (see Table 5). The life of the biogas plant was estimated at 15 years. The project was proven to be financially sound: its NPV amounts to $€ 1,221,213$ while its IRR stands at $28 \%$. The repayment period was fixed 15 years. The project was proven to be financially sound: 15 years. 
Table 5. Results of economic study (author's studies based on data from investor).

\begin{tabular}{lcc}
\hline \multirow{2}{*}{ Item } & \multicolumn{2}{c}{ Total cost [€/year] } \\
\cline { 2 - 3 } & projected & actual (2013) \\
\hline Investment expenditure & 787,966 & 787,966 \\
\hline Annual financial expenses & 141,834 & 141,834 \\
\hline Operating expenses without capital depreciation & $\mathbf{1 6 6 , 7 1 4}$ & $\mathbf{1 7 9 , 2 4 3}$ \\
\hline Cost of feedstock & 56,714 & $73,728^{\text {a }}$ \\
\hline CHP service and maintenance & 55,000 & 49,928 \\
\hline Other operating expenses (insurance, taxes, wages, servicing) & 50,000 & 55,587 \\
\hline Depreciation (of plant based on full life-cycle) & 210,124 & 210,124 \\
\hline Operating income & $\mathbf{5 3 7 , 2 5 8}$ & $\mathbf{2 8 8 , 9 8 7}$ \\
\hline Sales of electric energy & 179,539 & 171,272 \\
\hline Sales of "green" certificates (RES) & 289,220 & $117,715^{\text {b }}$ \\
\hline Sales of "yellow" certificates (CHP heat) & 68,499 & 34,249 \\
\hline a based on data regarding the amount of biomass used in Q3 2012; ${ }^{b}$ based on data from the Polish Energy \\
Exchange as of 20 June 2013 [14].
\end{tabular}

The project was proven to be financially sound: its NPV amounts to $€ 1,221,213$ while its IRR stands at $28 \%$. The repayment period was fixed at 8.4 years. Without EU grants covering $40 \%$ of the outstanding loan and a soft loan amounting to $75 \%$ of project costs, the project would be generating losses. Without the external funding, NPV would be negative at $-977,762$ euro. The current circumstances are hardly more conducive to the profitable operation of the plant. Rather than the initially projected PLN 300 per 1 MWh, investors can only count on earning ca. PLN 130. An added difficulty is that the yellow co-generation certificates were withdrawn from use at the start of 2013. The only certificates left are the violet certificates worth half the value of the yellow ones. Having accounted for recent data from the Polish Energy Exchange, the biomass volume used in Q3 2012 and the external funding secured for the biogas plant, the IRR was estimated at $-4 \%$ with the simple repayment period exceeding the installation's life.

\section{Conclusions}

As illustrated by the case of biogas plants, much work remains to be done in Poland in the field of renewable energy. While only 33 such plants are currently in operation, another 200 or so are in the pipeline. The growth of biogas plants as well as other renewable has been stunted by uncertainty about the future and the lack of clear rules governing the amount of support for the sector. The Law on renewable energy sources, which was due for adoption two years ago, has not moved beyond the preparation of its final draft. As legislative changes cannot be adopted before relevant input technologies have been developed, there will always be a delay before new regulations adapt to new technologies. Yet, the example of other European countries shows that renewable energy sources are no longer classified as innovative technologies and that they have graduated to be seen as well-tested power-generating installations. To remedy the situation in which no new installations are built while the existing ones generate no profit, the Polish government must act promptly and propose legislation to ensure a reliable predictable future for the sector in the long run. This can be achieved by 
providing a fundamental legislative environment for both the existing as well as the planned renewable energy installations.

Biogas plants supplied with food industry waste present the biggest growth opportunity available to the Polish renewable energy sector. Such plants are not only designed to produce energy from renewable natural sources but also, and primarily so, to solve the problem of how to dispose of organic waste. In addition, biogas plants built in the agri-food sector make the food industry more profitable. And yet, such installations will never be profitable without governmental support, reliable legislation on renewable sources of energy and EU co-financing. They are not set up for economic purposes but rather to improve the management of environmentally harmful waste and protect the natural environment by reducing carbon and methane emissions which contribute to the greenhouse effect.

\section{Author Contributions}

All authors have read and approved the final manuscript.

\section{Conflicts of Interest}

The authors declare no conflict of interest.

\section{References}

1. The European Parliament and the Council of the European Union. On the promotion of the use of energy from renewable sources and amending and subsequently repealing Directives 2001/77/EC and 2003/30/EC, Directive 2009/28/EC. Official Journal of the European Union, 5 June 2009, pp. 16-47.

2. The Energy Law, the Act of 10th of April 1997. Available online: http://www.ure.gov.pl/ download.php?s=2\&id=2 (accessed on 4 August 2014).

3. Jasiulewicz, M. Possibility of liquid bio-fuels, electric and heat energy production from biomass in Polish agriculture. Pol. J. Environ. Stud. 2010, 19, 479-483.

4. Agricultural Market Agency. Agricultural Biogas, data for 2011-2012. Available online: http://www. arr.gov.pl/index.php?option $=$ com_content\&view $=$ article\&id=1639\&Itemid=631 (accessed on 21 June 2013).

5. Żmuda, K. Biomass Potential in the Production of Agricultural Biogas in Poland. In Renewable Energy Sources as a New Challenge for Rural Areas in Poland; Kucharska, B., Ed.; Foundation of Assistance Programme for Agriculture (FAPA): Opole, Poland, 2009; pp. 17-20.

6. Ministry of Economics. Trends in the Development of Agricultural Biogas Plants in Poland in 2010-2020. Available online: http://www.mg.gov.pl/node/11898 (accessed on 29 June 2013).

7. Nges, I.A.; Escobar, F.; Fu, X.; Björnsson, L. Benefits of supplementing an industrial waste anaerobic digester with energy crops for increased biogas production. Waste Manag. 2005, 32, $53-59$.

8. Commission of the European Communities Green Paper follow-up action-Report on progress in renewable electricity. Available online: http://ec.europa.eu/energy/energy_policy/doc/06_ progress_report_renewable_electricity_en.pdf (accessed on 4 August 2014). 
9. Polish Economic Chamber of Renewable Energy (PECRE). Selected Key Comments to the Draft Act on Renewable Sources of Energy Published in October 2012. Available online: http://www.nowe-pe-pg-i-ustawa-o-oze.cire.pl/st,45,352, item,67117,6,0,0,0,0,0,wybrane-kluczoweuwagi-do-projektu-ustawy-o-odnawialnych-zrodlach-energii-opublikowanego-w-pazdzierniku-2012r.html (accessed on 29 June 2013).

10. Rusak, S.; Kowalczyk-Juśko, A. Biogas plants in Poland. Czysta Energ. 2007, 6, 68-73.

11. General Directorate Environmental Protection (GDEP). Available online: http://www.gdos.gov.pl/ Articles/view/2899/The_role_of_EIA (accessed on 29 June 2013).

12. Wawer, M. Why is There Social Resistance to the Construction of Agricultural Biogas Plants. In Proceedings of the Green Power Energy Conference, Warsaw, Poland, 12-15 October 2011; p. 3.

13. Institute for Sustainable Development (ISD). Alternative Energy Policy for Poland until 2030; Technical and Methodological Report; ISD: Warsaw, Poland, 2009. Available online: http://www. ineisd.org.pl/lang/pl/page/broszury/id/18/file/27/option/save/ (accessed on 29 June 2013).

14. Polish Power Exchange. Property Rights Market. Available online: http http://tge.pl/ en/464/property-rights-market (accessed on 21 June 2013).

(C) 2014 by the authors; licensee MDPI, Basel, Switzerland. This article is an open access article distributed under the terms and conditions of the Creative Commons Attribution license (http://creativecommons.org/licenses/by/3.0/). 